\author{
今 成司 \\ 日本電子 (株)（干196 東京都昭島市武蔵野 3-1-2）
}

\title{
Recent Progress of Nuclear Magnetic Resonance
}

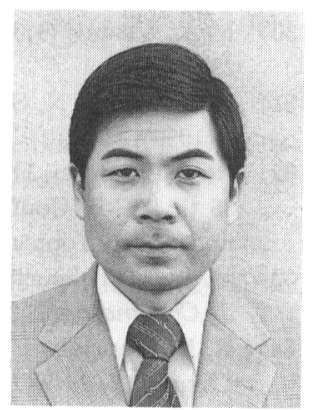

\author{
Mamoru IMANARI \\ Japan Electronic Optics Laboratory (JEOL) \\ (3-1-2, Musashino, Akishima-shi, =196)
}

\begin{abstract}
New NMR techniques have proliferated during the past 10 years. In the techniques, two dimensional NMR has been used as routin technique for structure analysis of unknown compounds.

High resolution NMR of solid become familiar and give the information of the structure and morphology of solid materials. NMR imaging has been rapidly developed and applied to new medical application field.

This article will introduce outline of the technical situation and some applications for each item, and discuss about future prospects of NMR.
\end{abstract}

\section{序言}

核磁気共鳴 (NMR) は有機化合物の構造情報を得る 手段として高分解能 NMR を中心に発展してきたがこ こ 10 年あまりの間に構造情報を得る手法の進歩もさる ことながら，全く別な応用面へも発展してきている。そ れらの中で特に急速に発展したのは二次元 NMR, 固体 高分解能 NMR, NMR イメージング (MRI) の三つの 分野である。二次元 NMR の進歩は元来一次元スペク トルより得ていた化合物の構造に関する情報〔ケミカル シフト $(\delta)$ やスピンースピン結合定数 $(J)$ ]をより正 確に得ることができるようになったと同時に情報を種々 分離する能力を持ったために複雑な化合物の構造解析を 可能にした。

固体高分解能 NMR の進歩は従来信号幅の中にうず もれていた構造に関する情報を観測することを可能にし た。その結果, 固体特有の構造情報のみならず物性に関 する情報も NMR から得られるようになってきてい る。

生体内の水の分布を画像化するNMR イメージング (MRI) の発展は臨床病理への NMR の応用を可能にし た。従来 X 線 CT で観測していた生体の断層映像は生 体内の固い部分を主体とした像であるが，NMR によっ て得られる断層映像は生体内の軟らかい部分から得られ る像である。従って, NMR イメージングは X 線 $\mathrm{CT}$ 相補する観点からも臨床医学において有用な武器となり
つつある。

上記のような NMR の進歩の原動力になっているの はやはりコンピュータの進歩上超伝導磁石の進歩であ る。コンピュータの進歩は膨大なデー夕を短時間で処理 し，かつ様々な形で表現することを可能にした。超伝導 磁石の進歩は高磁場の NMR を実用的なものにしたこ とにより NMR の $\mathrm{S} / \mathrm{N}$ と分解能を飛躍的に向上させ た。図-1に $90 \mathrm{MHz}, 270 \mathrm{MHz}, 500 \mathrm{MHz}$ で測定した ショウノウの ${ }^{1} \mathrm{H}$ NMR スペクトルを示す。こ机らのス ペクトルの比較により, 磁場強度による分解能差は一目 りょう然である。

また超伝導磁石は人間を入れるような大きな磁場を作 ることも可能にしたことも忘れてはならない。それによ り人体用の NMR イメージングの発展を促進させたと 言っても過言ではないからである。

ここではNMRにおける技術的な進歩と残された課 題, 今後の動向を個人的な見解も含めて紹介する。

\section{1 パルス技術の発展と二次元 NMR}

1970 年代になって急速に発展してきたフーリェ変換 NMR (FTNMR)により NMR は大きく変化した。

従来連続波 $(\mathrm{CW})$ を用いて観測していた方法に代わ りパルスを用いた FTNMR は飛躍的な感度の向上を達

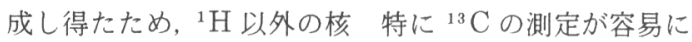
なったことは有機化合物の構造解析に多大の貢献をして いる。 
${ }^{1} \mathrm{H}$ Spectra at various field

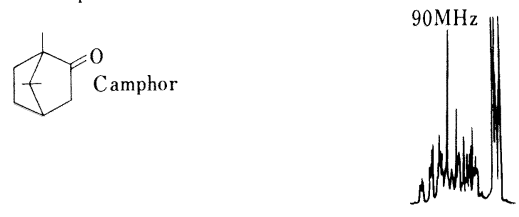

$270 \mathrm{MHz}$

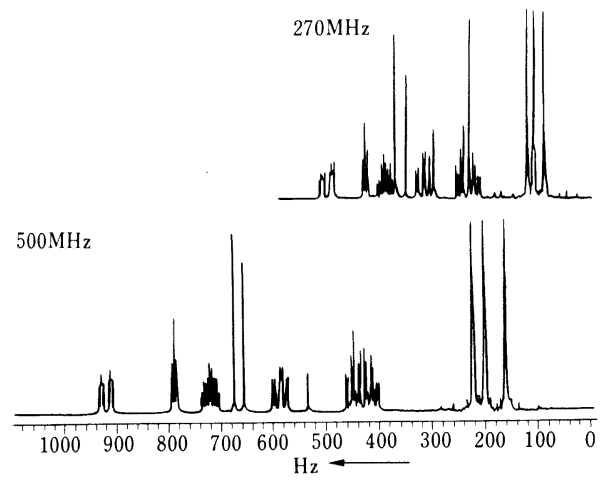

図-1 共鳴周波数の違いによる ${ }^{1} \mathrm{H}$ NMR スペ クトル

一方では種々のパルス技法が考案され, 測定方法も 種々改良されてきた。それらの中で INEPT ${ }^{1}$ や $\mathrm{DEPT}^{2)}$ の出現が特に注目される。もともとINEPTや DEPT は ${ }^{13} \mathrm{C}{ }^{15} \mathrm{~N}$ などの感度の悪い核の感度を向上 させるために ${ }^{1} \mathrm{H}$ の磁化を ${ }^{13} \mathrm{C} や{ }^{15} \mathrm{~N}$ に移す測定方法 である。ところが, ${ }^{13} \mathrm{C}$ と ${ }^{1} \mathrm{H}$ とのスピンースピン結合 によって, $\mathrm{CH}_{3}, \mathrm{CH}_{2}, \mathrm{CH} の{ }^{13} \mathrm{C}$ の信号はそれぞれ 4 重線, 3 重線, 2 重線に分裂するため, 分裂に基づく信号 の位相差を利用して、 $\mathrm{CH}, \mathrm{CH}_{2}, \mathrm{CH}_{3}$ の区別できるこ とが判明した。そのため INEPT やDEPT は $\mathrm{CH}$, $\mathrm{CH}_{2}, \mathrm{CH}_{3}$ の判別方法として使用されるようになって きた。通常 ${ }^{13} \mathrm{C}$ のスペタトルは ${ }^{1} \mathrm{H}$ のスピンースピン 結合による分裂のため複雑なスペクトルになることを辟 ける目的で ${ }^{1} \mathrm{H}$ をデカップルした状態で観測されてい る。従って、 ${ }^{13} \mathrm{C}$ のスペクトルは各信号が単一線になり 比較的単純なスペクトルになるが, 反面信号の帰属が困 難になる。そのため, INEPT や DEPT が考察される 以前はオフーレゾナンスデカップルにより ${ }^{1} \mathrm{H}$ とのスピ ンースピン結合をわずか残すことにより，信号の分裂の 状態によって, $\mathrm{CH}, \mathrm{CH}_{2}, \mathrm{CH}_{3}$ を判別していた。とこ ろが, INEPT やDEPT の出現により, ${ }^{13} \mathrm{C}$ の信号は ${ }^{1} \mathrm{H}$ をデカップルされた単一線の状態で $\mathrm{CH}, \mathrm{CH}_{2}, \mathrm{CH}_{3}$ の判別ができるようになったのである。従ってかなり複 雑なスペクトルにおいても容易に $\mathrm{CH}, \mathrm{CH}_{2}, \mathrm{CH}_{3}$ の区 別ができるようになった。

DEPTにおいては条件を変えて測定した複数のスペ クトルを編集することによって $\mathrm{CH}$ や $\mathrm{CH}_{2}$ や $\mathrm{CH}_{3}$ の みのスペクトルを作ることも可能である ${ }^{3)}$ 。図一2に
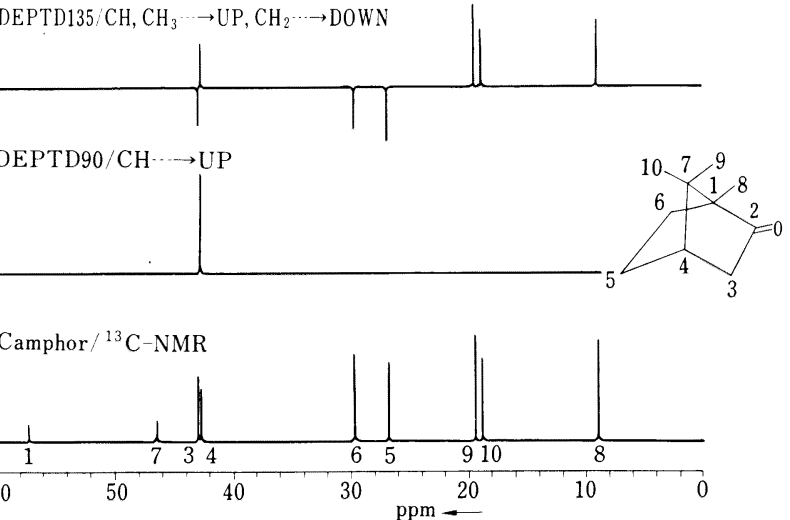

図-2 ショウノウの ${ }^{13} \mathrm{C} \mathrm{DEPT} \mathrm{スペクトル}$

ショウノウの DEPT スペクトルを示す。

パルス技術の中で最も注目されるのは二次元 NMRで ある。この方法は 1971 年に Jeenerによって最初に提 案され, その後 Ernst や Freeman 達のグループに よって 1970 年代の後半までかかって種々の基本的な方 法が確立された。現在では構造解析の常とう(套) 手段 になっている。二次元 NMR の基本的な時間系列は

準備時間 $\left|\begin{array}{|l|l}\text { 展開時間 } \\ t_{1} \longrightarrow\end{array}\right| \begin{aligned} & \text { 検出時間 } \\ & t_{2} \longrightarrow\end{aligned}$

のようになっているい'。展開時間 $\left(t_{1}\right)$ と検出時間 $\left(t_{2}\right)$ の関数として観測されたスペクトル群 $\mathrm{F}\left(t_{1}, t_{2}\right)$ を $t_{1}$ と $t_{2}$ で順次フーリエ変換することにより $\mathrm{F}\left(\omega_{1}, \omega_{2}\right)$ なる二次元のスペクトルが得られる。通常この時間は NMR の励起パルスやその位相の組み合わせにより作り 出さ机ている。従ってパルスや位相組み合わせにより 種々の二次元スペクトルが考案され, 実用化されてい る。主な二次元のパルス系列を図ー3に示す。

\section{$J$ 分解二次元スペクトル}

これはNMRのスペクトルに含まれている主な構造 情報である化学シフト $(\delta)$ とスピンースピン結合定数 $(J)$ とを分離し，二次元のそれぞ机のスペクトル軸に表 す方法である。この方法には同種核間の $J$ 分解二次元 之異種核間の $J$ 分解二次元 ${ }^{5)}$ がある。このスペクトルに おいては化学シフトとスピン結合定数 $(J)$ とがそれぞ れ $f_{2}$ 軸と $f_{1}$ 軸に分離されて観測されるため, 一次元ス ペクトルでは複雑に重なりあったスペクトルであっても スピン結合定数 $(J)$ を容易に読み取ることができる。 また $f_{2}$ 軸から $45^{\circ}$ 傾いた方向へ投影したスペクトルは スピンースピン結合のない単純なスペクトルになるた め, 信号の先端が化学シフトに一致する。しかしなが ら, $J$ 分解二次元は NMR 信号の位相情報を残して表現 できる観測方法でないため, コンピュータで処理する段 


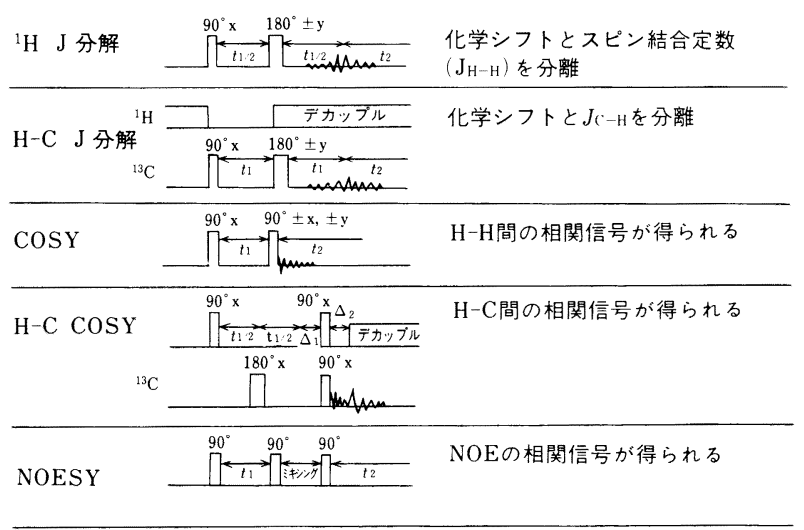

図-3 主な二次元 NMR のパルス系列

階で信号強度に対する精度は失われている。従って二次 元に表示された信号強度はもとの信号強度を忠実に表現 しているわけでないので, 信号の積分強度から定量性を 論じることはできない。

相関二次元スペクトル $(\mathrm{COSY})^{4)}$

これはスピンースピン結合をしているスピン間での相 関信号を得る方法である。図-4 にショウノウの ${ }^{1} \mathrm{H}$ の $\operatorname{COSY}$ スペクトルを示す。対角線上のスペクトルは一 次元スペクトルと同一スペクトルとなり, 非対角線上の 信号はスピンースピン結合を持つ信号間に現れるクロス ピークと呼ばれる相関信号である。従って相関信号によ
り隣接スピン間の相対的な信号位置を知ることができ, かつその隣接スピンを次々とたどればスピン結合のネッ トワークがわかるため, 化合物の平面構造が組み立てら れることになる。しかしながら現実にはスペクトルが複 雑であるため信号の判別ができなかったり, 堂素や酸素 を含む化合物ではスピン結合のネットワークがつながら なくなったりして, ${ }^{1} \mathrm{H}$ の COSY スペクトルのみでは分 子構造を組み立てることが不可能な場合が多い。

この相関二次元 NMR においても異種核間のスピン 結合を利用した異種核間相関スペクトルも観測される。 例として H-C COSY スペクトルを図ー5 に示す。この

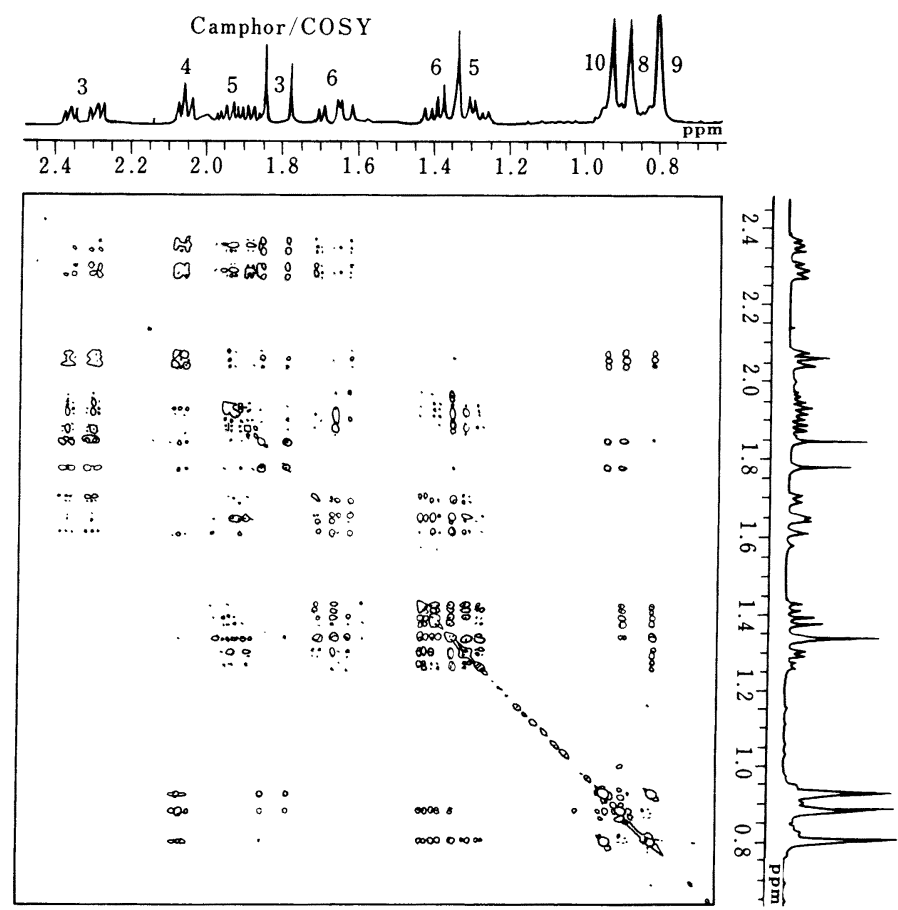

図-4 ショウノウの $\mathrm{H}-\mathrm{H} \operatorname{COSY}$ スペクトル 


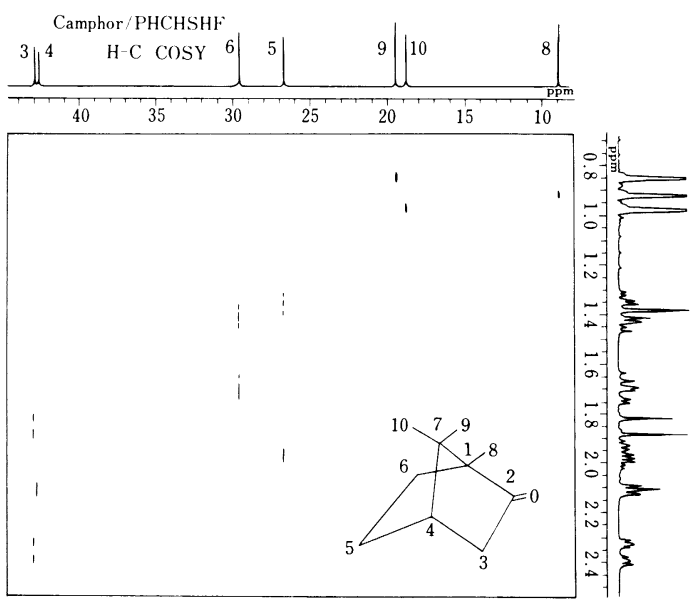

図-5 ショウノウの $\mathrm{H}-\mathrm{C} \operatorname{COSY}$ スペクトル

二次元スペクトルからは炭素に直接結合している ${ }^{1} \mathrm{H}$ の 信号位置や一つの炭素に結合している二個以上の ${ }^{1} \mathrm{H}$ が NMR 的に等価か, 非等価か，などの情報を得ることが できる。

またこれら $\mathrm{H}-\mathrm{H}$ COSY や $\mathrm{H}-\mathrm{C}$ COSY の測定にお いて遠隔スピン結合 (long rang スピン結合) を強調 した測定方法もある。この long range COSY スペク トルによって隣接炭素に結合した ${ }^{1} \mathrm{H}$ と ${ }^{13} \mathrm{C}$ よの相関 やさらに遠隔の炭素に結合した ${ }^{1} \mathrm{H}$ と ${ }^{13} \mathrm{C}$ との相関を 知ることができる。従って $\mathrm{H}-\mathrm{H}$ COSY や $\mathrm{H}-\mathrm{C}$ COS $\mathrm{Y}$, long range $\mathrm{H}-\mathrm{C}$ COSY より得られたスピン結合 のネットワークの情報を総合するこよにより，炭化水素 化合物の平面構造のかなりの部分が組み立てられること になる。

\section{NOE 二次元スペクトル $(\mathrm{NOESY})^{6)}$}

NOESY はスピン間の距離の情報を得ることのでき る測定法として重要である。NOEとは核オーバー八ウ ザー効果 (Nuclear Overhauser Effect) のことで，核 間の磁気双極子相互作用により，一方のスピンの作る磁 化に変化があると, 磁気双極子相互作用のあるもう一方 のスピンの作る磁化に変化が伝わる効果である。その磁 化の変化量の伝わる大きさはスピン間の距離の 6 乗に反 比例している。NOEの测定は一次元NMR スペクトル においても分子の立体構造の情報を得る手段として重要 な測定法の一つである。FTNMRにおいても磁化を変 化させたスペクトルと変化させない平衡状態のスペクト ルとの差をとり变化量のみを観測する差 NOE の測定は 重要な測定法の一つとして定着している。NOESY は 分子全体のスピン間の相対的な距離情報を得る手段とし て考案された二次元NMRである。特にタンパク質のよ うに高分子で複雑な一次元 NMR スペクトルを与える 化合物においては一次元差 NOE スペクトルを観測する
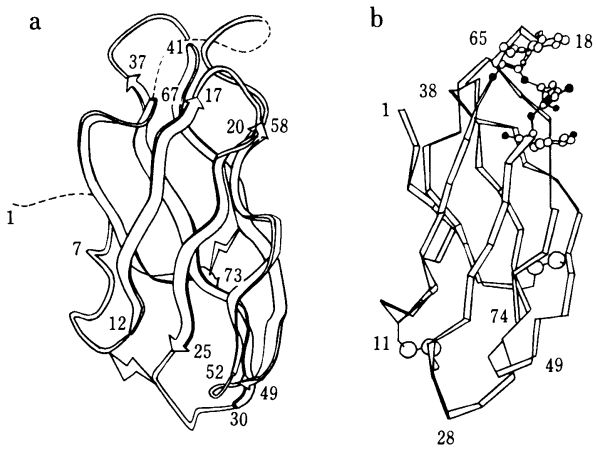

a) NMR データから distant geometry 法によって 求められた。 b) $\mathrm{X}$ 線解析から求められた立体構造.

図-6 テンダミスタットの立体構造

ことは不可能である。従ってこのような化合物によって NOESY はスピン間の距離情報を得る唯一の方法とし て, 非常に重要な測定法である。NOESY からスピン 間の距離情報が多くのプロトンについて得られるなら分 子の三次元構造の組み立ても可能になる。この NOESY の情報から分子の立体構造を組み立てるアルゴリズムを distance geometry 亡言い, 溶液中の分子の立体構造 を決める方法として最近非常に注目されている。この 計算方法も色々あり, 現在, $\mathrm{DADAS}^{7)}, \mathrm{AMBER}^{8)}$, GROMOS $^{3)}$, CHARMAN $^{10)}$, PROTEAN $^{11)}$ などの 計算方法が提案されている。図-6にNMR の情報から distance geometry 法を用いて決めたテンダミスタッ トの立体構造 ${ }^{12)}$ とそれとは全く別なグループが X 線解 析 ${ }^{13)}$ で決めた立体構造とを対比して示す。両者とも非 常に似た構造を示している。

その他にも二次元 NMR の方法は数多くある。例え ば炭素のつながりの情報を得るための ${ }^{13} \mathrm{C}-{ }^{13} \mathrm{C}$ の相関 を観测するINADEQUATE法 ${ }^{14)}$, ${ }^{1} \mathrm{H}$ のスピン系の連 鎖を観測する Relayed COSY ${ }^{15)}$, や HOHAHA ${ }^{16)}$, 回 転座標系内での NOE の情報を得る ROESY ${ }^{17)}$, さらに は ${ }^{1} \mathrm{H}$ を観測して $\mathrm{H}-\mathrm{C}$ COSY と同様の情報を感度良 く得る $\mathrm{HMQC}^{18)}$ や $\mathrm{HMBC}^{18)}$ など多くの二次元 $\mathrm{NMR}$ 法が実用化されている。

この様に数多く実用化されている二次元 NMR の方 法の中から目的に応じた方法を使い分けることにより分 子の構造に関する詳細な情報を得ることができる。

\section{2 固体高分解能 NMR}

固体の場合は分子運動が制限されているために隣接ス ピン間の磁気双極子相互作用や化学シフトの異方性によ り信号幅が広がる。そのため分子の構造情報を与える化 学シフトやスピンースピン結合による微細構造は信号幅 の中に隠れてしまい観測することができない。磁気双極 


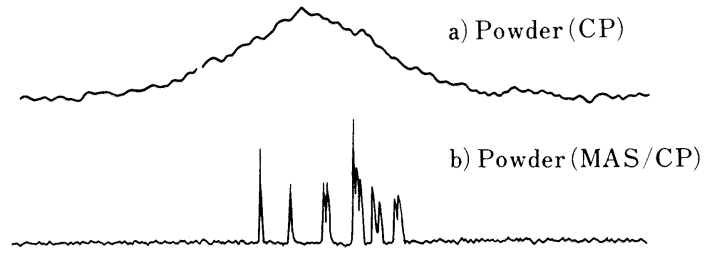

c) Solution

a) ${ }^{1} \mathrm{H}$ をデカップルした ${ }^{13} \mathrm{C}$ スペクトル. b) ${ }^{1} \mathrm{H}$ デ カップルとMAS (Magic Amgle Spinning) を行った スペクトル，c）溶液のスペクトル

図-7 ショ糖の固体 ${ }^{13} \mathrm{C} \mathrm{MNR} \mathrm{スペクトル}$

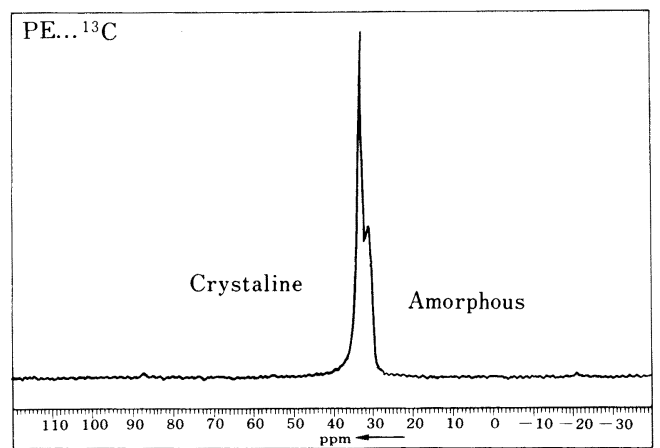

図-8 ポリエチレンの固体高分解能 ${ }^{13} \mathrm{C}$ スペクトル

子相互作用には同種核間の相互作用と異種核間の相互作 用がある。現在実用化されているのは異種核間の磁気双 極子相互作用を消して高分解能を得る方法であり, ${ }^{15} \mathrm{~N}$, ${ }^{29} \mathrm{Si},{ }^{13} \mathrm{C}$ などの観測に適用されている。

${ }^{13} \mathrm{C}$ の場合, 天然存在率が $1.1 \%$ と少ないから ${ }^{13} \mathrm{C}$ 同 士が隣接する確率は非常に小さいため同種核間の磁気双 極子相互作用は無視できる。従って，信号幅を広げてい る要因は隣接 ${ }^{1} \mathrm{H}$ との磁気双極子相互作用と化学シフト の異方性である。そこで ${ }^{1} \mathrm{H}$ からの磁気双極子相互作用 を除くために信号幅より大きい高周波磁場を作る共鳴周 波数で ${ }^{1} \mathrm{H}$ を照射する(デカップル)。さらに化学シフ トの異方性による信号幅の広がりを除くために磁場方向 に対して $54^{\circ} 44^{\prime}$ 傾いた軸を中心に高速で回転する (Magic Angle Spinning, MAS) ことによって高分解 能スペクトルを得ることができる。通常 ${ }^{13} \mathrm{C}$ の固体の 高分解 NMR の測定の場合は ${ }^{13} \mathrm{C}$ の感度を上げるため に ${ }^{1} \mathrm{H}$ の磁化を ${ }^{13} \mathrm{C}$ に移す交差分極 (Cross Polarization) の手法も併用されている。

図-7 にショ糖の固体と液体の ${ }^{13} \mathrm{C}$ スペクトルを示 す。図-7-a は $^{1} \mathrm{H}$ をデカップルした ${ }^{13} \mathrm{C}$ スペクトルで ある。化学シフトの異方性による信号幅の広がりが残っ ているため個々の ${ }^{13} \mathrm{C}$ の信号は分離して観測されてい

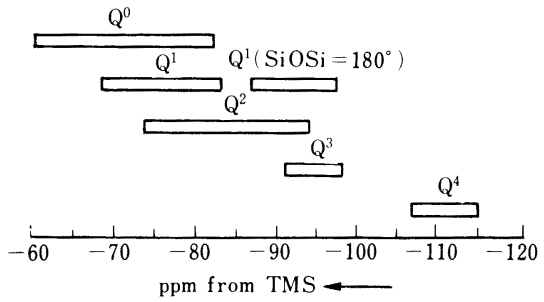

図-9 ケイ酸塩 ${ }^{29} \mathrm{Si}$ の化学シフト分布

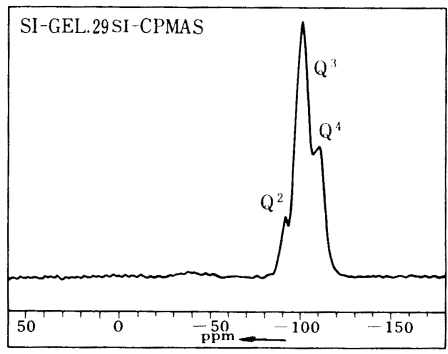

図-10 シリカゲルの ${ }^{29} \mathrm{Si} \mathrm{NMR} \mathrm{スペクトル}$

ない。図-7-b は ${ }^{1} \mathrm{H}$ のデカップルと Magic Angle Spinning を併用したスペクトルである。液体で観測さ れる信号（図-8-c）に相当する信号はすべて分離して 観測されている。

固体高分解能 NMR は合成高分子のキャラクタリ ゼーション, 溶媒に溶けない化合物の構造研究, 無機塩 や触媒などの構造解析など種々の方面に応用されつつあ る。

例えば高密度ポリエチレンの固体高分解能の ${ }^{13} \mathrm{C}$ NMR スペクトル $\left(\right.$ 図-8 ${ }^{19)}$ の場合, エチレンの信号が 結晶部分と非結晶部分に分かれて観測されている。

無機塩への応用としては ${ }^{29} \mathrm{Si}$ の测定例がある。ケイ 酸塩の場合，ケイ素原子のまわりの酸素を共有するケイ 素の数により， $\mathrm{Q}^{0}$ (ネソケイ酸塩) $\mathrm{Q}^{1}$ (ソロケイ酸塩), $\mathrm{Q}^{2}$ (イノケイ酸塩), $\mathrm{Q}^{3}$ (フィロケイ酸塩)， $\mathrm{Q}^{1}$ (テクトケ イ酸塩）と分類されている。 ${ }^{29} \mathrm{Si} の \mathrm{NMR}$ では $\mathrm{Q}^{0} \sim \mathrm{Q}^{4}$ の ${ }^{29} \mathrm{Si}$ の化学シフトが図-9のように分かれてい る ${ }^{20)}$ 。代表的なケイ酸塩であるシリカゲルの ${ }^{29} \mathrm{Si}$ のス ペクトルは図-10 に示すように $\mathrm{Q}^{2}, \mathrm{Q}^{3}, \mathrm{Q}^{4}$ に相当する 信号が観測される。従って $\mathrm{Q}^{2}, \mathrm{Q}^{3}, \mathrm{Q}^{4}$ の信号強度から 表面の状態などの知見を得ることができる。触媒として 知られているゼオライトで代表されるケイ酸塩において も $\mathrm{Si}-\mathrm{O}-\mathrm{Al}$ の数により ${ }^{29} \mathrm{Si}$ の化学シフトに差があ る。そのためゼオライトの ${ }^{29} \mathrm{Si}$ のスペクトルは $\mathrm{Si}$ のま わりの $\mathrm{Al}$ の数に応じて分離したスペクトルになる。図 -11に合成ゼオライトの ${ }^{29} \mathrm{Si}$ のスペクトルを示す。こ のスペクトル強度や信号の形からゼオライト中の $\mathrm{Al} の$ 含有量や構造に関する情報を得ることができる ${ }^{20)} 。$

固体高分解能 NMR は測定の際に, 隣接 ${ }^{1} \mathrm{H}$ の磁化 
$(\mathrm{Si} / \mathrm{Al})_{\mathrm{NMR}}^{\mathrm{Si}}=2.37$

(a)

$(\mathrm{Si} / \mathrm{Al})_{\mathrm{EDA}}=2.48$

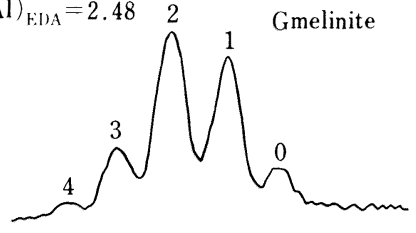

$(\mathrm{Si} / \mathrm{Al})_{\mathrm{NMR}}^{\mathrm{Si}}=2.30$

(b)

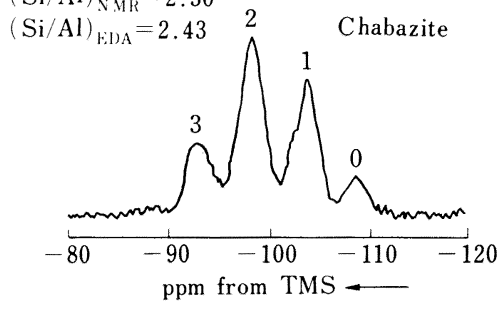

図-11 合成ゼオライトの ${ }^{29} \mathrm{Si}$ の NMR スペクトル<smiles>NC(Cc1c[nH]c2ccccc12)C(=O)O</smiles>

L.-Tryptophane

1000 scans

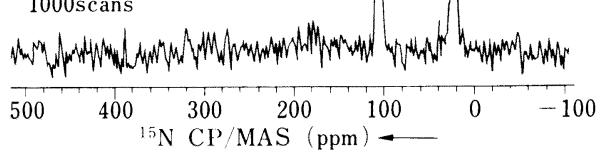

図-12 Lートリプトファンの固体高分解能 ${ }^{15} \mathrm{~N} \mathrm{NMR}$ スペクトル

を交差分極により観測核に移す方法 ${ }^{21)}$ を使用している ため, ${ }^{15} \mathrm{~N}$ のように非常に感度が覀いため液体の NMR で観測困難な核も比較的簡単に観測することができる。 図-12にL-トリプトファンの ${ }^{15} \mathrm{~N}$ の固体高分解能スペ クトルを示す。これは 1000 回の積算の結果得られたス ペクトルである。

以上のように固体高分解能 NMR の応用面は増々広 がってきており, 固体特有の情報が得られるようになっ てきている。しかしながら信号の䚻属に関する手法がま だ確立されていないため, 固体特有のスペクトルが観測 されてもその情報を生かしきれていない面も多い, 例え ば図ー13 に示すセドロールの ${ }^{13} \mathrm{C}$ のスペクトルのよう に, 固体と液体では全く異なったスペクトルになる。液 体のスペクトルは図-13-bのように信号は帰属される が固体のスペクトルにおいては帰属の方法が確立されて いない, 等方平均の化学シフトは液体の化学シフトと同 じであると解釈できるから液体のスペクトルから多くの 信号は帰属できるが，二本に分裂した信号も多く観測さ れているので完全に帰属することは困難である。また固
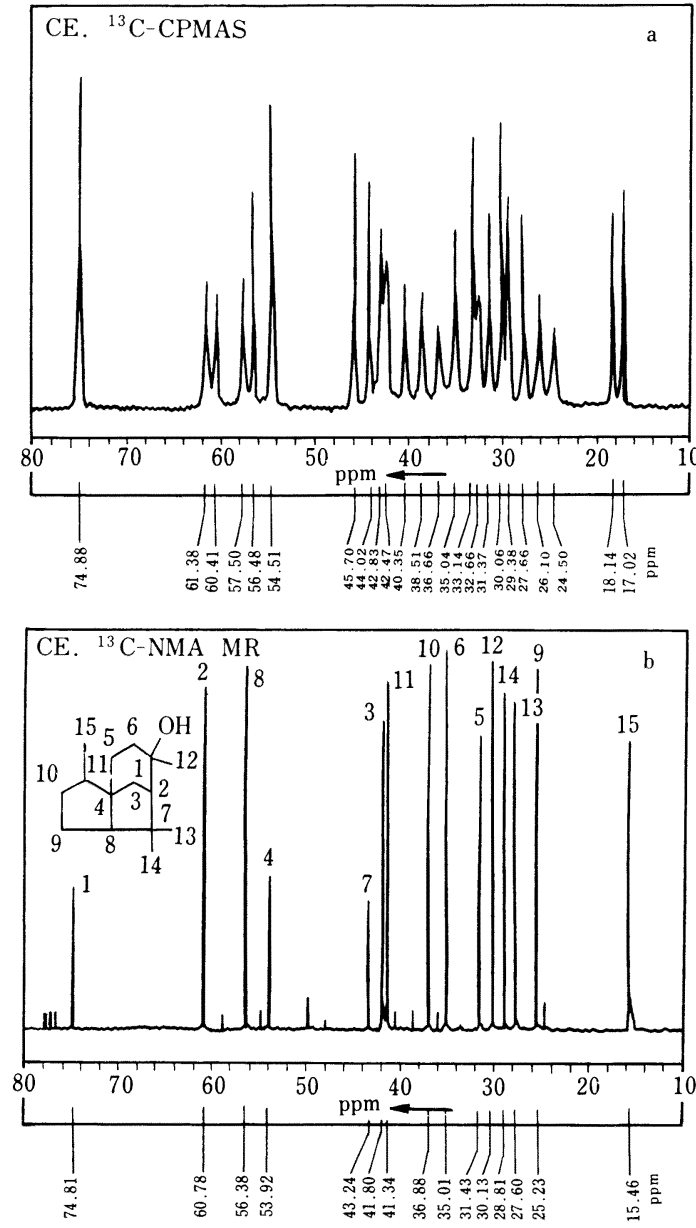

a) 固体高分解能スペクトル, b) 重クロロホルム 溶液のスペクトル

図-13 セドロールの ${ }^{13} \mathrm{C} \mathrm{NMR}$ スペクトル.

体のスペクトル中のいくつかの信号が分裂している点に おいてもその理由が明確になっていない。このように固 体特有のスペクトルの解釈についても今後の課題となっ ている。

また固体高分解能 NMR の測定技術においても今な お色々な方法が試みられている。例えば Magic Angle Spinning と多重パルスを組み合わせて ${ }^{1} \mathrm{H}$ の固体高分 解能スペクトルを観測する CRAMPS, 二次元 NMR の 手法を用い展開時間の間のみ回転軸を変えることにより 二次元スペクトルの一軸 $\left(f_{1}\right.$ 軸) に化学シフトの異方 性の情報を表現する $\mathrm{SASS}^{22)}$, 回転軸を変えることによ り核四極子モーメントの影響を平均化する $\mathrm{VASS}^{24)}$, VASS とMASを組み合わせた Double Angle Spinning (DAS) ${ }^{23)}$ など色々な方法が試みられている。こ れらの方法も将来次々と実用化されるであろう。 


\section{NMR イメージとin vivo での測定}

NMR 技術の最近の進歩の中で最もポピューラーなの は NMR イメージング (MRI) であろう。NMR イメー ジングの方法は Lauterber によって 1973 年 ${ }^{23)}$ に最初 に報告されている。その後 10 年むまりの間に急速に技 術が進み，大きな磁石の中に人間を入れて，人体の断層 映像を観測できるまでになってきている。現在では臨床 医学への応用も盛んで X 線 CT(Computer Tomography）上相補するまでになっている。

測定の原理は磁場勾配のある静磁場内の各点の核スピ ンの共鳴周波数が異なることに基づいている。一定磁場 勾配内での各部の共鳴周波数を位置情報上し, 各点に投 ける信号強度を二次元平面に地図之同様に表示すること により断層映像を作っている。現在実用化されているの は ${ }^{1} \mathrm{H}$ の NMR 信号密度を映像化する方法である。測 定の方法としてはX 線 CT と同様に多方向からの投影 スペクトルを再生する PR 法 (Projection reconstruction $)^{25) \cdot 26)}$ 上Spin warp 法 ${ }^{27)}$ に代表されるパルス磁場 勾配と RFパルスの組み合わせによる二次元 NMRの 手法を用いる測定法がある。

PR 法においては必要な分解能の断層像を得るため $1^{\circ}$ ステップで $180^{\circ}$ までの各方向からの投影スペクト ルが必要亡なる。Spin Warp 法においても 128 個もし くは2 56 個の一次元スペタトルから断層映像を作る。し かも NMR 現象には緩和現象があるため, 観測パルス の繰り返し時間をあまり短くすることができない。その ため, Spin Warp 法なよ゙では一回の観測の間に数か所 の断層映像を観測するなよ゙の工夫がされている。

NMR イメージングは，X 線 CT に対して以下のよう ないくつかのすぐれた特徴を持っている。
1)軟組織を画像化している。

2)磁場勾配のかけ方により縦, 横, 斜め, いずれ の方向の画像をも作ることができる。

3) NMR 現象特有の緩和時間 $\left(T_{1}, T_{2}\right)$ を用いるこ とにより，組織の物性を反映する像が得られる。

4) X 線を用いないため生体に無害である。

その反面, 大きな磁石を使用するため, 周囲に対する 磁場の影響があり，心臓のペースメーカーを持っている 人には危険, 近くに磁性のある計測器を近づけられな

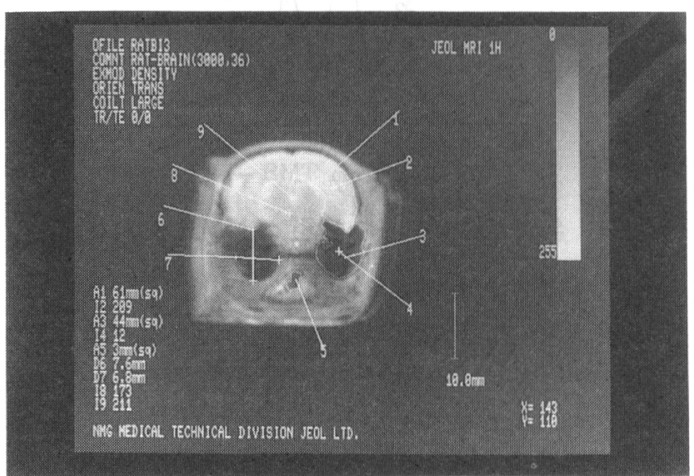

図-14 ラットの頭部の ${ }^{1} \mathrm{H}$ NMR による断層映像

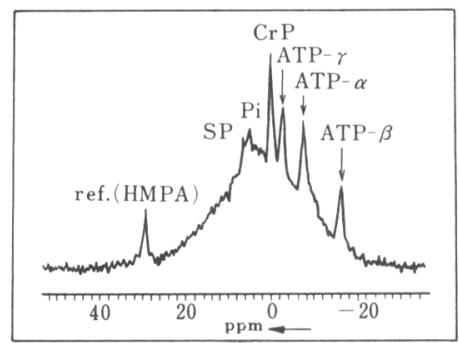

図-15 サーフェスコイルによって観測されたラット頭 部の ${ }^{31} \mathrm{P} \mathrm{NMR}$ スペクトル

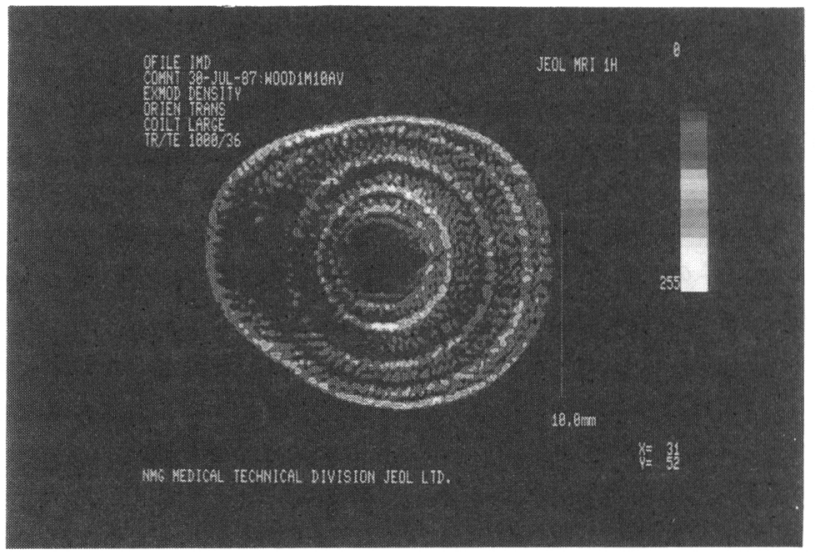

図-16 アオキの木の ${ }^{1} \mathrm{H}$ NMR による断層映像 
い, 液体へリウムを用いる磁石では維持費が高く手間が かかるなどの問題点もある。図一14にラットの頭部の断 層映像を示す。

一方映像からではなく, 生体内の局部の NMR スペ クトルを観測することによるエネルギー代謝に関する研 究も進んでいる。

この方面の仕事はサーフェスコイルを用いて局部の NMR スペクトルを観測することで進められている。観 測核としては ${ }^{31} \mathrm{P} か ゙$ 心である。 ${ }^{31} \mathrm{P}$ は天然存在率が 100\%のためNMR としては感度が良く, 組織内に 1 $\mathrm{mM}$ 程度存在すると観測可能である。図一15にラット の頭部の ${ }^{31} \mathrm{P} \mathrm{NMR}$ スペタトルを示す。ATP, クレア チンリン酸, 無機リン酸が明りょうに観測されている。 このスペクトルから新陳代謝が悪くなるとATP が減少 し無機リンが増加することが明確に観測できる。また NMR 信号の飽和を用い, クレアチンリン酸の信号のみ を飽和させるとその飽和現象が ATP に移る速度 (saturation transfer) を测定することができるため生体内 のエネルギー代謝速度に関する知見なよ゙も得ることがで きる。このようなエネルギー代謝の研究を小動物を用い て実施することは薬理効果や臓器移植に関する基礎実験 として重要視されている。

NMR イメージングの技術は固体物質の断層映像 ${ }^{28)}$ を得ることにも応用されつつある。図一16にアオキの木 の ${ }^{1} \mathrm{H}$ の断層映像を示す。こ机は木の中の水分の分布 を観測しているため年輪などの組織が比較的明りょう に観測されている。しかしながら，一般に固体の場合， NMRの信号幅は非常に広い，従って充分な分解能を得 るためには $100 \mathrm{G} / \mathrm{cm}$ 以上の大きな磁場勾配が必要に なる。もちろん信号幅の狭い成分のみ在断層映像とする 場合は小さな磁場勾配で良いが，少なくとも $10 \mathrm{G} / \mathrm{cm}$ 程度の磁場勾配は実用性から考えて必要であろう。これ は現在実用化されている生体用 NMR イメージングで 用いられている磁場勾配の 10 倍から 100 倍以上大きな 磁場勾配となる。このような大きな磁場勾配を on-off することは外部静磁場との相互作用があり技術的な困難 さを伴う、そのため，物質の NMR イメージングは実 験的には種々試みられているが, 実用化の段階には至っ ていない。

\section{おわりに}

ここまでに, 構造解析としての NMR, 固体の高分解 能 NMR, NMR イメージングの現状について紹介して きた。しかしながら NMR の技術面の進歩はまだまだ 止まることを知らない勢いで続いている。世界中の多く の研究者や技術者が色々な目的で研究開発を続けてい る。NMR は研究開発を続ける価値を持っているので ある。磁場においても, 磁場が強くなれば強くなるはよ゙
分解能が向上し, かつ感度が上がる, 従って高磁場を作 る努力が続けられているのである, 伝え聞くところによ ると. $750 \mathrm{MHz}$ や $900 \mathrm{MHz}$ の NMR の開発に挑戦し ている人達もいるようである。また測定法も多くの研究 者により工夫され続けられている。パルスの組み合わせ による必要な情報の選択や複雑に重なり合ったスペクト ルの分離の方法など色々な測定方法が考察され実用化さ 机てきている。特に二次元 NMR の分野においてはす でに三次元 NMR へと進んできている。三次元 NMR よしてはすでに $J$ 分解- $\mathrm{COSY}{ }^{29)}, \mathrm{COSY}-\mathrm{COSY}^{30)}$, NOESY-COSY ${ }^{31)}$,NOESY-HMQC ${ }^{32}$ なよ゙の実験例 が報告されている。これらの実験目的はいずれも複雑な スペクトルを多次元に分離することにより NMR スペ クトルからの分子の構造情報を容易に正確に取り出する ことにある。従って, このような方法が実用化され，コ ンピュータでの表示や解析の方法が確立されてくると現 在あきらめら扎ていたような複雑な高分子化合物もより 詳細な構造解析が可能になってくるであろう。しかしな がら三次元 NMR の测定は二次元 NMR スペクトルを 数十個一数百個取り込むことに相当するため非常に長い 時間 (数日間) を要する。従ってこの種の測定に対して はNMR 装置や設置環境に対する長時間の安定性が要求 されてくる。そのためNMR スペクトルの次元を増す 分光法に関しては実用上の面から限界がでてくるであろ うが、時間や装置の安定性及び NMR の持つ緩和時間 (特に信号の減衰) などを無視するといくらでも次元を 増すことができる。従って, NMR スペクトルの情報分 離の必要性に応じて三次元 NMR, 四次元 NMR, 亡 いった多次元NMR が実現する可能性がある。しかしな がら複雑な化合物は高分子であることが多く一般には緩 和時間 $\left(T_{2}\right)$ が短いことが多いため, その点からも実用 的な限界がでてくるであろう。

固体 NMR においても高分解能化の方法として CRAMPSなどの方法が盛んに試みられているため, 近い将来実用化されてくるであろう。その他にも固体の ままの構造や物性の情報を得たいとする要求が多くある ため, 色々な技術開発が行われている, 特に新素材の開 発を行っている研究者からの固体 NMR に対する期待 が多くあるため, 核四重極に関係した NMR 技術が進 むのではないかと予想される。

NMRイメージングとして現在臨木病理方面で実用化 さ机ているのは ${ }^{1} \mathrm{H}$ 密度のイメージングであるが, 生体 内で ${ }^{1} \mathrm{H}$ スペクトルを与える物質は水, 脂肪, タンパク 質なよ゙数多く存在している。現在はそれらの物質の重な りを映像化しているわけであるが，これらの物質を分離 して映像化しようとする化学シフトイメージングの方法 が試みられている。この方法が実用化されると, 生体内 組織に関するより詳細な情報を得ることができるように 
なるであろう。固体物質のイメージングにおいてもまだ まだ測定方法の開発が進められている段階である。

以上のようにNMR は多方面において実用化されて 多くの実績を上げている分光法であると同時に将来にお いてもまだ多くの夢を与えてくれる分光法と言えよう。

[平成元年 (1989) 5月 24 日受理]

\section{文献}

1) G.A. Morris, R. Freeman, J. Am. Chem. Soc., 101, 760 (1979) ; D. P. Burum, R. R. Ernst, J. Magn. Reson., 39, 163(1980)

2) M. D. Doddrell, D. T. Pegg, M. R. Bendall, J. Magn. Reson., 39, 163 (1982) ; M. R. Bendall, D. T. Pegg, J. Magn. Reson., 59, 237 (1984)

3) M. R. Bendall, D. T. Pegg, J. Magn. Reson., 53, 272 (1983)

4) W. P. Aue, E. Bartholdi, R. R. Ernst, J. Chem. Phys., 64, 2229 (1976) ; A. Bax, "Two-Dimentional Nuclear Magnetic Resonance in Liquid”, Delft University Press, Dordrecht (1982)

5) L. Muller, A. Kumar, R. R. Ernst, J. Chem. Phys., 63, 5490 (1975); G. Bodenhausen, R. Freeman, D. L. Turner, J. Chem. Phys., 65, 839 (1976)

6) S. Macura, R. R. Ernst, Mol. Phys., 41, 95 (1980)

7) W. Braun, N. Go, J. Mol. Biol., 186, 611 (1985)

8) P. Weiner, P. Kollman, J. Compt. Chem., 2, 287 (1981)

9) W. F. van Gusteren, H. J. C. Berendsen, Biochem. Soc. Trans., 10, 301 (1982)

10) R. A. Brooks, R. E. Brucoolieri, B. D. Olafson, D. J. States, S. Swaminathan, M. Karplus, J. Compt. Chem., 4, 189 (1983)

11) R. B. Altman, O. Jardetzky, J. Biochem., 100, 1403 (1986)

12) A. D. Kline, W. Braün, K. Wüthrich, J. Mol. Biol., 189, 377 (1986)

13) J. W. Pflugrath, G. Wiegand, R. Huber, L. Vertesy, J. Mol. Biol., 189, 383 (1986)

14) A. Bax, R. Freeman, S. P. Kempsell, J. Am. Chem. Soc., 102, 4849 (1980) ; A. Bax, R. Freeman, J. Am. Chem. Soc., 103, 2102 (1981)

15) S. K. Sarka, A. Bax, J. Magn. Reson., 63, 512 (1985)

16) D. G. Davis, A. Bax, J. Am. Chem. Soc., 107,
2820, $7197(1985)$

17) A.A. Bothner-By, R.L. Stephens, Ju-mee Lee, C. D. Warren, R. W. Jeanloz, J. Am. Chem. Soc., 106, 811 (1984); A. Bax, D. G. Davis, J. Magn.Reson., 63, 207(1985) ; L. Braunschweiler, R. R. Ernst, J. Magn. Reson., 53, 521 (1983)

18) A. Bax, M. F. Sumer, J. Am. Chem. Soc., 108, 2093 (1986) A. Bax, S. Subramanian, J. Magn. Reson., 67, 565 (1986)

19) I. Ando, T. Yamanobe, T. Sorita, T. Komoto, H. Sato, K. Deguchi, M. Imanari, Macromolecules, 17, 1955 (1984); W. L. Earl, D. L. Vander Hart, Macromolecules, 12, 762 (1979)

20) J. Felshe, B. Ketter, R. L. Schmid, Ihermochimica Acta , 88, 443 (1985) ; "Progress in Nuclear Magnetic Resonance Spectroscopy”, Vol. 16, Pergamon Press, Berlin (1984)

21) M. Mehring, "High Resolution NMR Spectroscopy in Solids" Springer-Verlag, Berlin (1976)

22) A. Bax, N.M. Szeverenyi, C.E. Maciel, J.Magn. Reson., 52, 147 (1983)

23) A. Samoson, E. Lippmaa, A. Pines, Mol. Phys., 65, 1013 (1988)

24) E. Oldfield, R.J. Kirkpatrick, Science, 227, 1537 (1985)

25) P. C. Lanterber, Nature, 242, 190 (1973)

26) P. Mansfield, P.G. Morris "NMR Imaging in Biomedicine” Academic Press., New York (1982); P. Mansfield, I.L. Pykett, J. Magn. Reson., 29, 355 (1978)

27) A. Kumar, D. Welti, R. R. Ernst, J. Magn. Reson., 18, 69 (1975), W. A. Edelstein, J. M. S. Hutchison, G. Johnson, T. Gadpath, Physics and Medicine in Biology, 28, 751 (1980)

28) J. M. Listerud, S. W. Sinton, G. P. Drohny, Anal. Chem., 61, 23 A (1989)

29) G. W. Vuister, R. Boelens, J. Magn. Reson., 73, 328 (1987)

30) C. Griesinger, O. W. S $\phi$ rensen, R. R. Ernst, J. Magn. Reson., 73, 574 (1987)

31) R. Guilard, S.S. Gerges, A. Tabrad, P. Richard, M. A. El Borai, C. Lecomte, J. Am. Chem. Soc., 109, 7228 (1987)

32) D. Marion, L. K. Kay, S. W. Sparkes, D. A. Torchia, A. Bax, J. Am. Chem. Soc., 111, 1515 (1989) 